\title{
Topical diltiazem and glyceryl-trinitrate for chronic anal fissure: A meta-analysis of randomised controlled trials
}

\author{
Edward J Nevins ${ }^{1}$ (D), Venkatesh Kanakala ${ }^{1}$ (D) \\ ${ }^{1}$ South Tees Hospitals Nhs Foundation Trust, Clinic of General Surgery, Middlesbrough, United Kingdom
}

\begin{abstract}
Objective: Surgical management of chronic anal fissure can result in permanent fecal incontinence. Topical treatments have a lower risk of severe complication and are less expensive than surgical intervention. Rates of healing and compliance with topical agents vary in the reported literature. The aim of this study was to compare healing rates, incidence of headaches, and recurrence rates of chronic anal fissure in patients treated with topical diltiazem (DTZ) and topical glyceryl-trinitrate (GTN), with a view of identifying which agent should be used as first line non-operative therapy.

Material and Methods: Randomized controlled trials (RCTs), published since January 2000, comparing topical DTZ and GTN for treatment of chronic anal fissure were identified and compared. End points included healing rates, headache due to treatment, and late recurrence ( $>12$ weeks). A random effects meta-analysis model was used to compare outcomes.

Results: All studies used $2 \%$ DTZ and $0.2 \%$ or $0.5 \%$ GTN, and treatment was continued twice daily for between 6-12 weeks. Nine RCTs compared rates of healing with topical DTZ $(n=379)$ and GTN $(n=351)$, there was no difference between the two groups [RR $1.04(0.93-1.16)$, $p=0.48]$. Eight RCTs reviewed incidence of headaches, DTZ was better tolerated [RR $0.15(0.07-0.34), p<0.00001]$. Four RCTs reported late recurrence rates, DTZ was superior [RR 0.51 (0.27-0.96), $p=0.04]$.
\end{abstract}

Conclusion: Topical DTZ and GTN result in comparable healing rates; however, DTZ is superior with regards to headaches and late recurrence rates. DTZ should therefore be considered as first line non-operative treatment for chronic anal fissure.

Keywords: Chronic anal fissure, topical therapy, diltiazem, glyceryl-trinitrate

Cite this article as: Nevins EJ, Kanakala V. Topical diltiazem and glyceryl-trinitrate for chronic anal fissure: A meta-analysis of randomised controlled trials. Turk J Surg 2020; 36 (4): 347-352.

Corresponding Author

Edward J Nevins

E-mail: dr.e.nevins@gmail.com

Received: 31.08 .2020

Accepted: 19.09 .2020

Available Online Date: 29.12.2020

o Copyright 2020 by Turkish Surgical Society Available online at www.turkjsurg.com

DOI: $10.47717 /$ turkjsurg.2020.4895

\section{INTRODUCTION}

Anal fissure is a lineal tear in the anal canal distal to the dentate line (1). Chronic anal fissure (CAF) is associated with hypertonia of the internal sphincter resulting in mucosal ischaemia and failure to heal, which results in severe anal pain $(2,3)$. Resolution of the symptoms can be achieved by lowering the resting anal tone, and increasing blood flow. Historically, this was achieved by division of the muscle fibers, in the form of a lateral sphincterotomy. This was the mainstay of treatment, however, lateral sphincterotomy causes significant morbidity with reported incontinence rates of up to $30 \%$ (4).

Topical treatment of CAF with Diltiazem (DTZ) and Glyceryl-trinitrate (GTN) can result in good outcome, without the risk of surgery and incontinence. In the UK, topical GTN is considered first line therapy for CAF, and clinicians are advised to use analgesics concurrently for the management of side effects such as headache, DTZ is only considered after this (5). This meta-analysis of randomized controlled trials (RCTs) aimed to assess healing, headache and recurrence rates of CAF in adult patients treated with topical DTZ and GTN.

\section{MATERIAL and METHODS}

The search engines Ovid Medline, Embase, PubMed, Scopus and Google Scholar were used to identify publications. Search terms used were "chronic anal fissure", "glyceryl-trinitrate", "diltiazem", "healing," "side effect," "randomized" in exploded and linked combinations. Complete articles published in English since January 2000 were considered for inclusion. Articles identified were RCTs which compared out- 
comes of topical DTZ vs topical GTN in the management of CAF. All articles pertaining to acute anal fissure, systemic therapies, or surgical therapies were excluded. This search strategy is summarized in Figure 1. Primary outcomes included rates of healing, headaches and reported recurrence, which were collected by a single author (EJN).

A meta-analysis was performed by combining the results of outcome variables. Data were summarized using risk ratio. Heterogeneity among the studies was estimated using chi-squared $\left(x^{2}\right)$ tests which were reported as the $I^{2}$ statistic to estimate the percentage of total variation across studies attributable to study heterogenicity. A random effects meta-analysis model was used to account for the possible clinical diversity and methodological variation amongst the studies. All p-values were 2-sided. A significant difference was defined as $p<0.05$. Statistical analysis was conducted with Review Manager Version 5.3 (Cochrane Collaboration, Software Update, Oxford, UK).
Ethical approval for this research was not required owing to it being a meta-analysis of previously published (and approved) RCTs.

\section{RESULTS}

A total of 9 RCTs were identified, they incorporated 385 patients who were treated with DTZ and 371 in the GTN group (Table 1). All studies used between 6 and 12 weeks of treatment using 2\% DTZ and $0.2 \%$ or $0.5 \%$ GTN twice daily. Follow up ranged from 6 weeks to 52 weeks following completion of treatment.

Across the 9 studies, 277/379 (73.1\%) of the patients treated with DTZ had healed. A total of 244/351 (69.5\%) of the patients treated with GTN had healed. There was therefore no significant difference in healing rates between the two groups $(p=0.48)$ (Figure 2).

Eight studies reported rates of headaches during treatment. Only $31 / 359$ (8.6\%) of those treated with DTZ reported headache. The

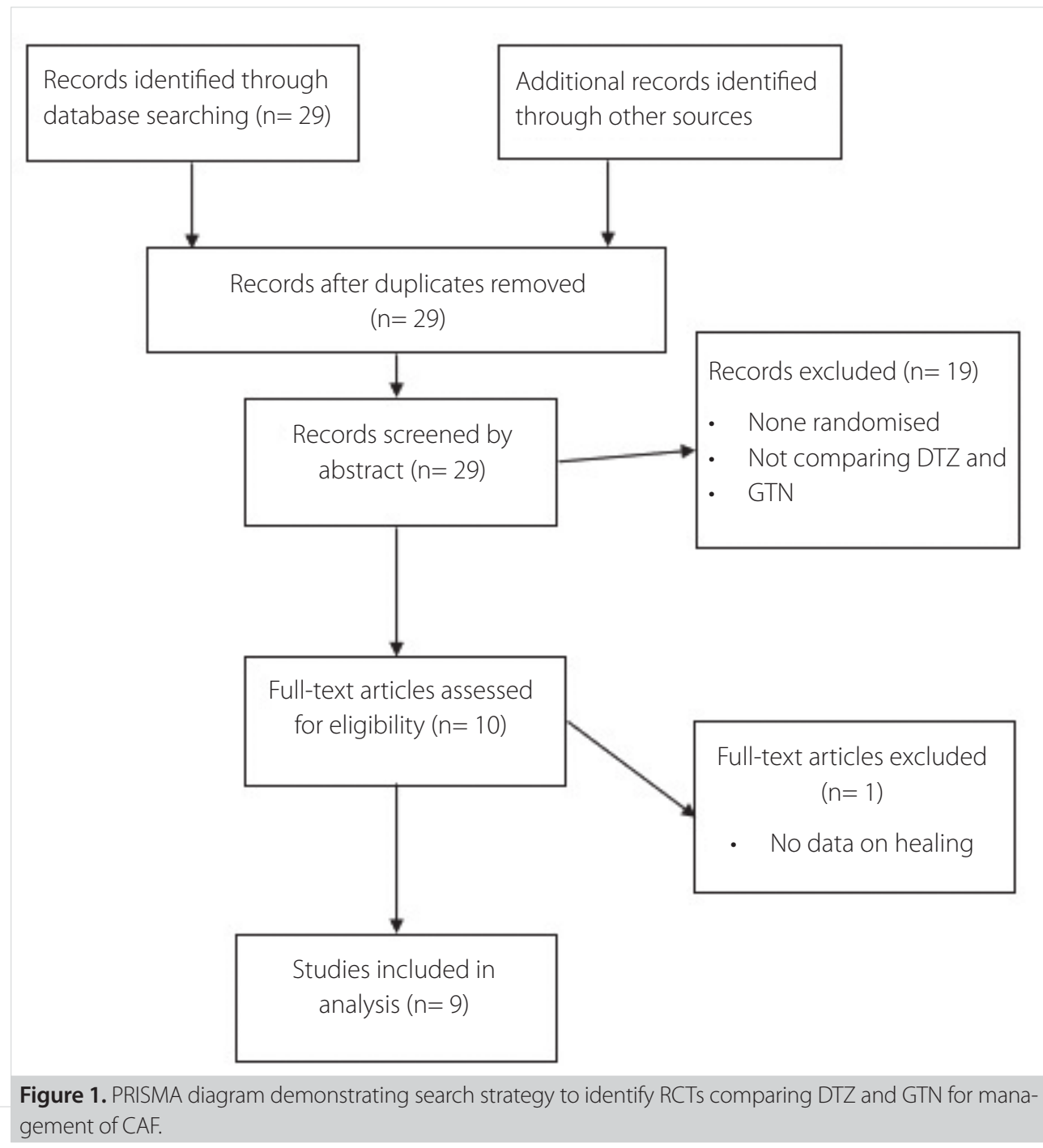


Table 1. Data extracted from RCTs comparing GTN and DTZ for CAF

\begin{tabular}{|c|c|c|c|c|c|c|c|}
\hline Author & DTZ group & GTN group & Treatment length & Follow up & Blinding & Randomisation protocol & Source of funding \\
\hline Bielecki $2002^{5}$ & 22 & 21 & $\mathrm{BD} 8 / 52$ & $8 / 52$ & $?$ & & $?$ \\
\hline Kocher $2002^{6}$ & 31 & 29 & $\mathrm{BD} 6-8 / 25$ & $12 / 52$ & Double & Computer generated & $?$ \\
\hline Shrivastava $2006^{7}$ & 30 & 30 & $\mathrm{BD} 6 / 25$ & $3 / 12$ & $?$ & Drawing lots & $?$ \\
\hline Jawaid $2009^{8}$ & 40 & 40 & $\mathrm{BD} 8 / 52$ & $8 / 52$ & $?$ & Computer generated & $?$ \\
\hline Sanei $2009^{9}$ & 51 & 51 & $\mathrm{BD} 12 / 52$ & $8-12 / 52$ & Double & Computer generated & $?$ \\
\hline Suvarna $2010^{10}$ & 100 & 100 & $\mathrm{BD} 6 / 52$ & $52 / 52$ & $?$ & Sequential order & None \\
\hline Ala $2012^{11}$ & 36 & 25 & $\mathrm{BD} 8 / 52$ & $8 / 52$ & Double & Computer generated & $?$ \\
\hline Bansal $2016^{12}$ & 25 & 25 & $\mathrm{BD} 6 / 52$ & $3 / 12$ & $?$ & Computer generated & $?$ \\
\hline Venkatesh $2019^{13}$ & 50 & 50 & $\mathrm{BD} 8 / 52$ & $6 / 52$ & $?$ & $?$ & None \\
\hline Total & 385 & 371 & & & & & \\
\hline
\end{tabular}

\begin{tabular}{|c|c|c|c|c|c|c|c|c|c|c|c|}
\hline \multirow[b]{2}{*}{ Study or Subgroup } & \multicolumn{2}{|c|}{ DTZ } & \multicolumn{2}{|c|}{ GTN } & \multicolumn{3}{|c|}{ Risk Ratio } & \multirow{2}{*}{\multicolumn{4}{|c|}{$\begin{array}{c}\text { Risk Ratio } \\
\text { M- } \mathrm{H}, \text { Random, } 95 \% \mathrm{Cl}\end{array}$}} \\
\hline & Events & Total & Events & Total & Weight & M-H, Random, $95 \% \mathrm{Cl}$ & Year & & & & \\
\hline Bielecki $2002^{5}$ & 19 & 22 & 18 & 21 & $12.5 \%$ & $1.01[0.79,1.28]$ & 2002 & & & & \\
\hline Kocher $2002^{6}$ & 8 & 31 & 12 & 29 & $2.0 \%$ & $0.62[0.30,1.30]$ & 2002 & 4 & & & \\
\hline Shrivastava $2006^{7}$ & 24 & 30 & 22 & 30 & $10.3 \%$ & $1.09[0.82,1.44]$ & 2006 & & & & \\
\hline Jawaid $2009^{8}$ & 32 & 38 & 33 & 35 & $19.0 \%$ & $0.89[0.76,1.05]$ & 2009 & & & & \\
\hline Sanei $2009^{9}$ & 34 & 51 & 28 & 51 & $8.7 \%$ & $1.21[0.89,1.66]$ & 2009 & & & & \\
\hline Suvarna $2010^{\circ}$ & 69 & 96 & 58 & 85 & $16.1 \%$ & $1.05[0.87,1.28]$ & 2010 & & & & \\
\hline Ala $2012^{11}$ & 33 & 36 & 15 & 25 & $7.9 \%$ & $1.53[1.09,2.14]$ & 2012 & & & & \\
\hline Bansal $2016^{12}$ & 20 & 25 & 18 & 25 & $8.8 \%$ & $1.11[0.81,1.52]$ & 2016 & & & & \\
\hline Venkatesh $2019^{13}$ & 38 & 50 & 40 & 50 & $14.7 \%$ & $0.95[0.77,1.17]$ & 2019 & & & & \\
\hline Total $(95 \% \mathrm{Cl})$ & & 379 & & 351 & $100.0 \%$ & $1.04[0.93,1.16]$ & & & & & \\
\hline Total events & 277 & & 244 & & & & & & & & \\
\hline \multicolumn{8}{|c|}{$\begin{array}{l}\text { Heterogeneity: } \text { Tau }^{2}=0.01 ; \mathrm{Ch}^{2}=12.65, \mathrm{df}=8(P=0.12) ; \mathrm{l}^{2}=37 \% \\
\text { Test for overall effect: } Z=0.71(P=0.48)\end{array}$} & 0.5 & ${ }^{0.7}{ }^{1}$ & $\begin{array}{r}1.5 \\
\text { Favours DTZ }\end{array}$ & 2 \\
\hline
\end{tabular}

Figure 2. Forrest plot demonstrating rates of healing in patients with CAF treated with DTZ and GTN.

\begin{tabular}{|c|c|c|c|c|c|c|c|c|c|c|c|}
\hline \multirow[b]{2}{*}{ Study or Subgroup } & \multicolumn{2}{|c|}{ DTZ } & \multicolumn{2}{|c|}{ GTN } & \multicolumn{3}{|c|}{ Risk Ratio } & \multirow{2}{*}{\multicolumn{4}{|c|}{$\begin{array}{c}\text { Risk Ratio } \\
\text { M-H, Random, } 95 \% \mathrm{Cl}\end{array}$}} \\
\hline & Events & Total & Events & Total & Weight & M-H, Random, $95 \% \mathrm{Cl}$ & Year & & & & \\
\hline Kocher $2002^{6}$ & 8 & 31 & 17 & 29 & $17.7 \%$ & $0.44[0.23,0.86]$ & 2002 & & $\rightarrow-$ & & \\
\hline Shrivastava $2006^{7}$ & 0 & 30 & 20 & 30 & $6.1 \%$ & $0.02[0.00,0.39]$ & 2006 & & & & \\
\hline Sanei 20099 & 0 & 51 & 30 & 51 & $6.1 \%$ & $0.02[0.00,0.26]$ & 2009 & $\longleftarrow$ & & & \\
\hline Jawaid $2009^{8}$ & 9 & 40 & 27 & 40 & $18.0 \%$ & $0.33[0.18,0.62]$ & 2009 & & $\rightarrow-$ & & \\
\hline Suvarna $2010^{\circ}$ & 5 & 96 & 57 & 85 & $16.4 \%$ & $0.08[0.03,0.18]$ & 2010 & & & & \\
\hline Ala $2012^{11}$ & 0 & 36 & 25 & 25 & $6.1 \%$ & $0.01[0.00,0.22]$ & 2012 & $\longleftarrow$ & & & \\
\hline Bansal $2016^{12}$ & 2 & 25 & 9 & 25 & $12.5 \%$ & $0.22[0.05,0.93]$ & 2016 & & & & \\
\hline Venkatesh $2019^{13}$ & 7 & 50 & 23 & 50 & $17.2 \%$ & $0.30[0.14,0.64]$ & 2019 & & 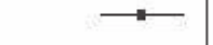 & & \\
\hline Total $(95 \% \mathrm{Cl})$ & & 359 & & 335 & $100.0 \%$ & $0.15[0.07,0.34]$ & & & & & \\
\hline Total events & 31 & & 208 & & & & & & & & \\
\hline $\begin{array}{l}\text { Heterogeneity: Tau } \\
\text { Test for overall effec }\end{array}$ & $\begin{array}{l}0.87 ; \mathrm{Ch} \\
Z=4.53\end{array}$ & $\begin{array}{l}z=30.2 \\
P<0.0\end{array}$ & $\begin{array}{l}22, d f=7 \\
10001)\end{array}$ & $(P<0$. & $.0001) ;\left.\right|^{2}=$ & $=77 \%$ & & 0.005 & $\begin{array}{c}0.1 \\
\text { Opposes GTN }\end{array}$ & $\begin{array}{c}10 \\
\text { Opposes DTZ }\end{array}$ & 200 \\
\hline
\end{tabular}

Figure 3. Forrest plot demonstrating rates of headache in patients with CAF treated with DTZ and GTN.

rates of headache in those treated with GTN was significantly worse, 208/335 (62.1\%) ( $p<0.0001)$ (Figure 3).

Four RCTs reviewed late recurrence rates ( $>12$ weeks) of CAF following completion of treatment. Recurrence rates were higher in the group treated by GTN compared to DTZ, 23/123 (18.7\%) vs $13 / 143(9.1 \%)$ respectively $(p=0.04)$ (Figure 4$)$. 


\begin{tabular}{|c|c|c|c|c|c|c|c|c|c|c|c|}
\hline \multirow[b]{2}{*}{ Study or Subgroup } & \multicolumn{2}{|c|}{ DTZ } & \multicolumn{2}{|l|}{ GTN } & \multicolumn{3}{|c|}{ Risk Ratio } & \multirow{2}{*}{\multicolumn{4}{|c|}{$\begin{array}{c}\text { Risk Ratio } \\
\text { M- } \mathrm{H}, \text { Random, } 95 \% \mathrm{Cl}\end{array}$}} \\
\hline & Events & Total & Events & Total & Weight & M- $\mathrm{H}$, Random, $95 \% \mathrm{Cl}$ & Year & & & & \\
\hline Kocher 2002 & 0 & 31 & 2 & 29 & $4.5 \%$ & $0.19[0.01,3.75]$ & 2002 & $\leftarrow$ & & & \\
\hline Shrivastava 2006 & 4 & 30 & 10 & 30 & $37.2 \%$ & $0.40[0.14,1.14]$ & 2006 & & - & & \\
\hline Suvarna 2010 & 6 & 62 & 9 & 46 & $43.9 \%$ & $0.49[0.19,1.29]$ & 2010 & & & 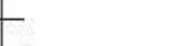 & \\
\hline Bansal 2016 & 3 & 20 & 2 & 18 & $14.5 \%$ & $1.35[0.25,7.19]$ & 2016 & & & & \\
\hline Total $(95 \% \mathrm{Cl})$ & & 143 & & 123 & $100.0 \%$ & $0.51[0.27,0.96]$ & & & & & \\
\hline Total events & 13 & & 23 & & & & & & & & \\
\hline \multicolumn{8}{|c|}{$\begin{array}{l}\text { Heterogeneity: } \text { Tau }^{2}=0.00 ; \mathrm{Chi}^{2}=1.95, \mathrm{df}=3(\mathrm{P}=0.58) ; \mathrm{I}^{2}=0 \% \\
\text { Test for overall effect: } Z=2.10(\mathrm{P}=0.04)\end{array}$} & 0.05 & ${ }^{0.2}$ Favours DTZ & Favours GTN & 20 \\
\hline
\end{tabular}

Figure 4. Forrest plot demonstrating rates of late recurrence in patients with CAF treated with DTZ and GTN.

\section{DISCUSSION}

Due to the risk of fecal incontinence and the financial cost of operative management, there has been a shift from operative intervention for the treatment of CAF to non-operative treatment modalities. Surgery is now typically reserved for treatment resistant CAF (15). Moreover, systemic therapy for CAF is poorly tolerated due to side effects $(2,16)$. For this reason topical therapies, with low side effect profiles, have been assessed.

Nine RCTs published since 2000 have been identified which compared topical DTZ and GTN. This meta-analysis has demonstrated comparable healing rates with DTZ (73.1\%) when compared to GTN (69.5\%). However, recurrence rates were twice as high in the GTN group. Moreover, rates of headache were significantly higher in the GTN cohort. Furthermore, Ala et al. have demonstrated faster symptom resolution with DTZ when compared to GTN (12). All of these reasons point towards the use of DTZ as first line therapy for the topical management of CAF. This report validates previously published reviews which have also demonstrated favorable outcomes with topical DTZ rather than GTN $(17,18)$

Importantly, the NHS drug tariff for DTZ is less than that for GTN. The tariff for DTZ cream is $£ 17.59$ (DTZ $2 \%$ cream $30 \mathrm{~g}$ ), and DTZ ointment is even less, $£ 13.44$ (DTZ 2\% ointment 30 g). 0.4\% GTN ointment (Rectogesic $30 \mathrm{~g}$ ) is significantly more expensive and costs $£ 39.30$ (19). This should be considered as another reason for considering DTZ as first line therapy.

\section{Limitations}

This meta-analysis has reviewed all randomized controlled trials reviewing DTZ and GTN for CAF. All publications used very similar treatment regimens (Table 1); however, not all publications reported a standard definition for CAF, this may be one of the reasons for the slight variation in reported results across studies. In addition, RCTs included in the present analysis used either $0.5 \%$ or $0.2 \%$ GTN. All 8 RCTs that compared rates of headache demonstrated favorable outcomes in the DTZ group. Therefore, we believe that even the lower dose preparation is less likely to be tolerated when compared to DTZ. It is, however, possible that this dose variability may have impacted upon other outcomes in the present analysis, such as recurrence or healing. Nevertheless, two previously published RCTs have failed to demonstrate that increasing concentrations of GTN affect healing rates in CAF $(20,21)$.

Despite all of the trials included in this study being RCTs, there remains significant risk of bias (Table 1). Only 3 of the studies reported if the assessors or patients were blinded; and we must therefore assume that the rest were not, therefore there is significant risk of observer bias in these trials. Two also failed to report their randomization methods, which again questions their validity. Furthermore, only 2 publications report their funding sources.

\section{CONCLUSION}

This meta-analysis has identified comparable healing rates for DTZ and GTN. However, DTZ results in fewer headaches and fewer late recurrences. DTZ should therefore be considered as first line non-operative treatment for chronic anal fissure.

Ethics Committee Approval: Ethical approval for this research was not required owing to it being a meta-analysis of previously published (and approved) RCTs.

Peer-review: Externally peer-reviewed.

Author Contributions: Concept - E.J.N., V.K.; Design - E.J.N., V.K.; Supervision - E.J.N., V.K.; Resource - E.J.N., V.K.; Data Collection and/or Processing - E.J.N., V.K.; Analysis and Interpretation - E.J.N., V.K.; Literature Review - E.J.N., V.K.; Writing Manuscript - E.J.N., V.K.; Critical Reviews - E.J.N., V.K.

Conflict of Interest: The authors declare that they have no conflict of interest.

Financial Disclosure: The authors declared that this study has received no financial support.

\section{REFERENCES}

1. Knight JS, Birks M, Farouk R. Topical diltiazem ointment in the treatment of chronic anal fissure. Br J Surg 2001; 88: 553-6. [CrossRef ]

2. Carapeti EA, Kamm MA, Phillips RKS. Topical diltiazem and bethanechol decrease anal sphincter pressure and heal anal fissures without side effects. Dis Colon Rectum 2000; 43: 1359-62. [CrossRef]

3. Lund JN, Scholefield JH. Aetiology and treatment of anal fissure. Br J Surg 1996; 83: 1335-44. [CrossRef] 
4. García-Aguilar J, Montes CB, Perez JJ, Jensen L, MadoffRD, Wong WD. Incontinence after Lateral internal sphincterotomy: Anatomic and functional evaluation. Dis Colon Rectum 1998; 41: 423-7. [CrossRef]

5. Natl Institue Heal Care Excell. Anal Fissure. 2017 [cited 2020 Jun 3]. Available from: https://cks.nice.org.uk/anal-fissure\#!scenario [CrossRef]

6. Bielecki K, Kolodziejczak M. A prospective randomized trial of diltiazem and glyceryltrinitrate ointment in the treatment of chronic ana fissure. Color Dis 2003; 5: 256-7. [CrossRef]

7. Kocher HM, Steward M, Leather AJM, Cullen PT. Randomized clinical trial assessing the side-effects of glyceryl trinitrate and diltiazem hydrochloride in the treatment of chronic anal fissure. Br J Surg 2002; 89: 413-7. [CrossRef]

8. Shrivastava UK, Jain BK, Kumar P, Saifee Y. A comparison of the effects of diltiazem and glyceryl trinitrate ointment in the treatment of chronic anal fissure: a randomized clinical trial. Surg Today 2007; 37: 4825. [CrossRef]

9. Jawaid M, Masood Z, Salim M. Topical diltiazem hydrochloride and glyceryl trinitrate in the treatment of chronic anal fissure. J Coll Physicians Surg Pak 2009; 19: 614-7. [CrossRef]

10. Sanei B, Mahmoodieh M, Masoudpour H. Comparison of topical glyceryl trinitrate with dialtazem ointment for treatment of chronic anal fissure. A randomized clinical trial. Ann Ital Chir 2009; 80: 379-83. [CrossRef]

11. Suvarna R, Hunamanthappa M, Panchami, Rai G. Topical diltiazem versus topical glyceryl trinitrate (GTN) in the treatment of chronic anal fissure: prospective study. Int J Biol Med Res 2012; 3: 1747-50. [CrossRef]

12. Ala S, Saeedi M, Hadianamrei R, Ghorbanian A. Topical Diltiazem vs. topical Glyceril trinitrate in the treatment of chronic anal fissure: a prospective, randomized, double-blind trial. Acta Gastroenterol Belg 2012; 438-42. [CrossRef]

13. Bansal AR, Kumar Yadav P, Godara R, Pal N, Tripura R, Jaikaran. Comparative evaluation of $0.2 \%$ glyceryl trinitrate vs. $2 \%$ diltiazem ointment in treatment of chronic anal fissure treatment - a randomized trial. Hell J Surg 2016; 88: 25-30. [CrossRef]
14. Venkatesh S, Kulkarni SB, Kruthi SR. Topical diltiazem versus topical glyceryl trinitrate in the treatment of chronic anal fissure: a prospective comparative study. Int Surg J 2019;6. [CrossRef]

15. Nelson RL, Thomas K, Morgan J, Jones A. Non surgical therapy for anal fissure. Cochrane Database Syst Rev 2012; 2012(2): CD003431. [CrossRef]

16. CookTA, Smilgin Humphreys MM, McC Mortensen NJ. Oral nifedipine reduces resting anal pressure and heals chronic anal fissure. Br J Surg 1999; 86: 1269-73. [CrossRef]

17. Nelson RL, Manuel D, Gumienny C, Spencer B, Patel K, Schmitt K, et al. A systematic review and meta-analysis of the treatment of anal fissure. Tech Coloproctol 2017; 605-25. [CrossRef]

18. Sajid MS, Whitehouse PA, Sains P, Baig MK. Systematic review of the use of topical diltiazem compared with glyceryltrinitrate for the nonoperative management of chronic anal fissure. Color Dis 2013; 15: 19-26. [CrossRef]

19. National Health Service England and Wales Electronic Drug Tariff [Internet], 2020. Available from: www.drugtariff.nhsbsa.nhs. uk/\#/00774110-DC/DC00774097/Home [CrossRef]

20. Scholefield JH, Bock JU, Marla B, Richter HJ, Athanasiadis S, Pröls M, et al. A dose finding study with $0.1 \%, 0.2 \%$, and $0.4 \%$ glyceryl trinitrate ointment in patients with chronic anal fissures. Gut 2003; 52: 264-9. [CrossRef]

21. Bailey HR, Beck DE, Billingham RP, Binderow SR, Gottesman L, Hull TL, et al. A study to determine the nitroglycerin ointment dose and dosing interval that best promote the healing of chronic anal fissures. Dis CoIon Rectum 2002; 45: 1192-9. [CrossRef] 


\section{ORIJINAL ÇALIŞMA-ÖZET}

Turk J Surg 2020; 36 (4): 347-352

\section{Kronik anal fissür tedavisinde topikal diltiazem ve gliseril-trinitrat: Randomize kontrollü çalışmaların meta-analizi}

Edward J Nevins ${ }^{1}$, Venkatesh Kanakala ${ }^{1}$

1 NHS Vakfı South Tees Hastaneleri, Genel Cerrahi Kliniği, Middlesbrough, Ingiltere

\section{ÖZET}

Giriş ve Amaç: Kronik anal fissürün cerrahi tedavisi kalıcı fekal enkontinansa neden olabilir. Topikal tedavilerde ciddi komplikasyon riski daha düşüktür ve bu tedaviler cerrahi müdahaleden daha ucuzdur. Literatürde topikal ajanlarla iyileşme ve uyum oranları değişiklik göstermektedir. Bu çalışmanın amacı, topikal diltiazem (DTZ) ve topikal gliseril-trinitrat (GTN) ile tedavi edilen hastalarda iyileşme oranlarını, baş ağrısı vakaları ve kronik anal fissür nüks oranlarını birinci basamak non-operatif tedaviler kapsamında karşılaştırmaktır.

Gereç ve Yöntem: Ocak 2000'den beri yayımlanan, kronik anal fissür tedavisi için topikal DTZ ve GTN'yi karşılaştıran randomize kontrollü çalışmalar (Randomized Controlled Trials) tespit edilerek karşılaştırılmıştır. Karşılaştırma noktaları iyileşme oranları, tedaviye bağlı baş ağrısı ve geç nüks etme (> 12 hafta) olarak belirlenmiştir. Sonuçları karşılaştırmak için bir randomize meta-analiz modeli kullanılmıştır.

Bulgular: Tüm çalışmalarda \%2 DTZ ve \%0,2 veya \%0,5 GTN kullanılmıştır ve tedavi 6-12 hafta boyunca günde iki kez uygulanmıştır. Dokuz çalışmanın topikal DTZ $(n=379)$ ve GTN $(n=351)$ ile iyileşme oranları karşılaştırıldığında, iki grup arasında fark olmadığı görülmüştür (RR 1,04 [0,93$1,16], p=0,48)$. Baş ağrısı vakalarının incelendiği 8 çalışmada, DTZ'nin daha iyi tolere edildiği görülmüştür (RR 0,15 [0,07-0,34], $p<0,00001)$. Geç nüksetme oranlarının karşılaştıııldığı 4 çalışmada, DTZ'nin daha iyi olduğu tespit edilmiştir (RR 0,51 [0,27-0,96], p=0,04).

Sonuç: Her ne kadar Topikal DTZ ve GTN arasında iyileşme oranları arasında bir fark olmasa da baş ağrısı ve geç nüksetme değişkenlerinde DTZ'nin daha iyi olduğu görülmüştür. Bu nedenle DTZ, kronik anal fissür için birinci basamak non-operatif tedavi olarak düşünülmelidir.

Anahtar Kelimeler: Kronik anal fissür, topikal tedavi, diltiazem, gliseril trinitrat

Doi: $10.47717 /$ turkjsurg.2020.4895 